Marquette University

e-Publications@Marquette

History Faculty Research and Publications

History, Department of

$12-1-2015$

\title{
A Running Fight against Their Fellow Men: Civil War Veterans in Gilded Age Literature
}

James Marten

Marquette University, james.marten@marquette.edu

Published version. The Journal of the Civil War Era, Vol. 5, No. 4 (December 2015): 504-527. DOI. (C) 2015 University of North Carolina Press. Used with permission. 


\section{A Running Fight against Their Fellow Men Civil War Veterans in Gilded Age Literature}

The most famous fictional soldier of the Civil War is arguably Henry Fleming, whose brush with cowardice helped inspire an iconic portrayal of courage under fire. Far less well-known is Stephen Crane's sketch of Henry's life after the war, the short story "The Veteran." Published in 1896, a year after The Red Badge of Courage, the tale projects Fleming into a vaguely contented late middle age. His younger neighbors listen to Henry's war stories, including the incident in which Henry succumbs to and then masters his panic in the face of mortal danger. The townsmen laugh a bit, but Henry's little grandson, Jim-perhaps named after Henry's old comrade Jim Conklin-is troubled that his hero could ever have run from danger.

Later that night, a barn fire breaks out. The other men, untested by life or death crises, rush about ineffectually. Henry quietly takes charge and makes a half dozen trips into the inferno to save the valuable livestock trapped inside. His hip is smashed and hair is burned off, but the cattle and horses are rescued. "The Veteran" showed that once a man has come to grips with his mortality and learned to manage his fear, the strength he drew from the terror and accomplishment would last the rest of his life. ${ }^{1}$

But there is an undercurrent flowing beneath the main plot, a tone that conveys a strange, if subtle, sense of unease. Henry is admired by his neighbors but seems almost to be a stranger to them, someone from the distant past. Henry's clarity of purpose and simple valor separate him absolutely from his duller neighbors. One senses that the long decades between the war and the fire had softened the civilians' understanding of the veterans' sacrifices and contributions and that Henry Fleming feels a nebulous sense of dissatisfaction at the lack of obvious respect.

Crane's portrayal of a veteran out of sync with the rest of society is a gentler version of other fictional accounts of former soldiers who did not fit into peacetime society. And those stories and novels reflected vigorous Gilded Age debates-especially in the North-over the nature of volunteerism, the definition of "worthy" veterans, and the role of old soldiers in 
the nation's politics. Not all "old soldiers" were honored equally, as some were seen as less worthy of admiration than others and the notion that they should continue to be rewarded through pensions for service they had offered voluntarily encountered sometimes violent opposition.

The surprising ambivalence with which their countrymen viewed veterans seeped into American fiction between the end of the Civil War and the early twentieth century. This is not surprising, given that so many Americans were veterans of the Civil War. Military service was the most common denominator of middle-aged northern and southern men during the Gilded Age. Forty-one percent of all northern white men born between 1822 and 1845 and 81 percent of those born in 1843 served in the Union army. As many as three-fourths of all white men of military age living in the Confederate states served in the Confederate army. ${ }^{2}$

In some cases, the veteran status of main characters is simply a plot device; the stories are not about the men as veterans. Although they might retain some element of military discipline and patriotism, they are not seen as struggling to come to grips with the aftermaths of military service. That they are veterans is important only in that it provides a character trait that comes with easy-to-identify qualities and roots them in a certain time and place. For instance, a little-known 1884 novel by a former officer in a black regiment depicted southern Klansman as depraved murderers, although it distinguishes between the honorable Confederates who had laid down their arms peacefully and the cowards, deserters, and "wannabe" Rebels who lashed out through sadistic terrorism. A generation later, the heroes imagined in Thomas Dixon's Klan are also, for the most part, Confederate veterans, but they reveal that status through loyalty, discipline, and a devotion to law and order (as they saw it, at least). The most out-of-place Civil War veteran in all of American literature may be Edgar Rice Burroughs's former Confederate John Carter, who first appeared in the 1911 serialization, Under the Moon of Mars, but later appeared in a number of other novels. None of these characters come to grips with being a veteran. ${ }^{3}$

A pair of novels provides a somewhat more nuanced portrayal of the lives of former soldiers, although they, too, fail to grapple with the psychological and public policy facets of veteranhood, choosing instead to focus on larger social issues. Col. Comfort Servosse, the "fool" in Albion Winegar Tourgée's 1879 A Fool's Errand, suffers "some trouble in or about one lung, no one seems to know just where, and some other mementos of the affectionate regard of our rebel friends," and his long absence at the front has ruined his prewar law practice. Both conditions were not unusual for veterans, but Servosse cheerfully proposes to go South, where, he assures his wife, the bitterness has subsided and they can begin anew. That is not how 
it works out, of course. Although from time to time Tourgée does mention the restlessness of veterans (one shrewd southerner remarks on meeting Servosse that "no active-minded man can settle down after four years of war to the every-day life of former years, without more than one twinge of restlessness and vague regret"), for the most part he applies his observations on the effects of the war to society rather than to individuals. ${ }^{4}$

Tourgée's purpose was to expose northern innocence, southern racism, and African American hopelessness, so it is not surprising that he was unable to explore more deeply the plight of a hard-used veteran. A quarter century after the appearance of $A$ Fool's Errand, the African American novelist Charles W. Chesnutt's The Colonel's Dream revisited the racial dynamics of the South through the experiences of another veteran colonel, this time a Confederate. Henry French lost his family and his property in the war and relocated to New York at the invitation of a kind relative. He makes good and after selling his business at a huge profit many years later returns to his hometown. Like Servosse, French has grandiose and naïve ideas about reconciliation and racial uplift that end in violence and his exile to the North. French's status as a veteran plays an even less important role than Servosse's; in the "List of Characters," in fact, Chesnut calls him a "retired merchant" and his military service is rarely mentioned. ${ }^{5}$

Even the title character in William Dean Howells's The Rise of Silas Lapham tells us little about the struggles of veterans, despite the centrality of the war to his life. Lapham's war service (he is yet another literary colonel) earns him the respect of his men, leaves him carrying a bullet in his leg, and nearly ruins the business he left behind when he joined the army. But through a somewhat dubious set of business decisions, he rises to wealth and social prominence as a paint merchant. His eventual fall is due to other poor decisions and bad luck but also to the drain of his continuing and ill-considered financial support of the family of a man who had died saving Lapham's life during the war. Commentators have generally seen Lapham as representative of major changes in the American economy and society-but not as a commentary on the status of veterans in that society. ${ }^{6}$

A few other fictional veterans represent the reconciliationist spirit of the times. The mid- to-late Gilded Age has long been seen as a period in which sectional differences receded and national unity strengthened. David Blight's Race and Reunion showed how this prevailing attitude among veterans encouraged the Confederate Lost Cause mentality and allowed southern whites to implement Jim Crow and disfranchise African Americans. Although Blight's paradigm has been challengedmost recently by Caroline Janney in Remembering the Civil War: Reunion and the Limits of Reconciliation-reconciliation remains an important 
thread in the veteran narrative and in the literature of the period. Indeed, Tourgée's and Chesnutt's veteran protagonists base their optimistic relocation to the South on their ultimately false assumption that reconciliation has already occurred and that the South has entered a postracial period. ${ }^{7}$

That was the case not in fact but in fiction; however, it was possible to remove race from the equation altogether, helping characters provide witness to a successful reconciliation between North and South. A heartwarming short story by Thomas Nelson Page features a former Confederate captain turned railroad conductor, who helps passengers endure a Christmas Eve journey from New York to New Orleans by passing out eggnog and telling war stories. The title character of an early-twentiethcentury western, Keith of the Border, provides a somewhat more complicated picture of reconciliation. Keith had fought hard for the Confederacy throughout the war, and although he "had enjoyed that life," the strenuous years of almost ceaseless fighting, of long night marches, of . . lonely scouting within the enemy lines, of severe wounds, hardship, and suffering, had left their marks on both body and soul." His father had been killed and his family home ruined; although he tried to make a life in the postwar South, his service "made such a task impossible; the dull, dead monotony of routine, the loneliness, the slowness of results, became intolerable." He headed west and made a life as a hunter, cowboy, and scout. But even this vaguely discontented Confederate veteran made peace with his enemies (although his "Confederate spirit" prevented him from actually joining the United States Army); he finds his real calling as a frontier scout, reporting to none other than Gen. Philip Sheridan. ${ }^{8}$

Edward Lucas White employed veterans to demonstrate the power of the reconciliationist spirit in a 1908 short story in the Atlantic Monthly. In it, an American living in the town of Middleville, on the Eastern Shore of Maryland, shows a visiting Frenchman "an experiment" that demonstrates the true American character sought by the foreigner. After the visitor admits to the hard feelings that still separated families in La Vendée region of France, which had been riven by civil wars during the French Revolution, his host asks, "Don't you think ... that that is rather a peevish and childish way to behave?" The Frenchmen stiffens, and an awkward conversation follows, in which he unsuccessfully tries to convince the American that such feelings were rooted in history and human nature. All this takes place during a carriage ride to the local cemetery. When they arrive, the American points out the gravestones of prominent townsmen as well as those of his father, his uncle, and other family members who had died in the Civil War. They fought for the Union, says the visitor solemnly, noticing the American flags on their graves. "You were never more 
mistaken in your life," the American retorts: many of the men buried under the little American flags had fought for the Confederacy. ${ }^{9}$

He goes on to explain that in this border state, where families-including his own-had been deeply divided, the veterans had led the effort to bury the past and unite around a common future. The foreigner was astonished that such hard feelings could have softened so quickly and assumed that they had not run so deep after all. The American corrects his guest again with a long tale of a group of veterans-some Confederate, some Union-sitting together, talking about the war. They discovered, in the kind of coincidences that Victorian authors relished, that they had fought on many of the same battlefields. Moreover, some had actually fired the shots that had killed friends and taken off the limbs of the very men with whom they were sharing a porch. The stories are gruesome, though the old men told them without bitterness, but with heavy emotion; the grief at having lost friends and comrades still burdened them.

Yet after they told their sad tales, admitted their past anger, processed their grief-the stories were always followed by uneasy silences-they all agreed that they had each of them had done his duty. They went to bed and the next day walked "arm in arm" down to the cemetery to put the tiny American flags on the graves of the men who had fought one another in the war. The American's story ends with the following tribute to reconciliation: while others might brag about the United States' commercial power and industrial might, he maintained, what was really remarkable was that no other nation "ever had what that flag stands for.... I'm dead sure no nation ever produced anything to compare with the spirit in which our differences have resulted.... That's something worth being proud of." The Frenchman agrees and asks to take one of the tattered flags home as a souvenir. ${ }^{10}$

The veterans in "The Little Faded Flag" display the reconciliationist ideal that resided at both the center of the story and at the center of American society at the turn of the twentieth century. It may not be easy for them to forgive and forget-indeed, their long conversation about past battles is at times painful and extraordinarily uncomfortable. But life itself has not proven overwhelming, and these men have settled into their roles as respected, if occasionally sad, old soldiers. They may well represent the majority of living and literary veterans, with the latter acting as dignified props in the service of a larger political statement.

The same might be said for the veteran who appears on the edges of Willa Cather's 1905 short story "The Sculptor's Funeral," in which rather embittered west Kansans receive the body of a now-famous townsman who had long ago sought his fortune in the East. Among the small group of nebulously unhappy men who gather to meet the train lurks a man in a 
faded blue "Grand Army suit." Ever present but nearly wordless, "the spare man with an ingratiating concession in his shrill voice," who "always carried the flag at the G. A. R. funerals," has just one line, when he remarks "It's too bad he didn't belong to some lodge or other. I like an order funeral. They seem more appropriate for people of some reputation." ${ }^{11}$

Despite his minor role in this story about a prodigal son, small-town jealousy, and provincial narrow-mindedness, Cather's veteran brings to the story more than just an unpleasant bit of stage business. He is a tiny example of how the complex portrayals of Civil War veterans in popular writing and literature belied common assumptions about the place of veterans in postwar America and reflected the complicated relationship between the men who had fought the war and the rest of American society.

While fairly extensive, the sample of stories and novels that appears here is not exhaustive. The ideas are presented thematically rather than chronologically, with examples drawn freely from various points in the forty or fifty years covered by the literature. The thematic qualities and values and experiences did not emerge from the literature in a well-ordered chronology but appeared from time to time throughout the era.

The presentation of these fictional old soldiers reflects the fact that, especially in the North, the legacy of veterans' service was confounded by disability, debates over pensions, and the remarkable political clout wielded by the Grand Army of the Republic (GAR). At another level, the presence of hundreds of thousands of crippled or disadvantaged veterans sparked debates about the worthy poor, the responsibility of government to "care for him who shall have borne the battle"-Lincoln's famous promise in his second inaugural address - and the uncomfortable and undeniable fact that veterans did not simply return to their communities and families and pick up where they left off. ${ }^{12}$

The veterans portrayed by these authors represented several ways civilians perceived them: as dependent, if sometimes dignified, paupers requiring aid but deserving only pity; as men whose valiant service and continuing sacrifices were almost immediately forgotten by their communities; as a source of humor and parody; and, ultimately, as examples of how a man-even with a life-changing disability-should buck up and get on with his life. ${ }^{13}$

One way or another, almost of all of these stories address the issue of masculinity. Some contemporaries suggested and a number of historians have agreed that the Gilded Age witnessed a "crisis in masculinity," which led to a fair amount of hand-wringing and theorizing about the nature of manhood. Although one might think that Civil War veterans would be natural models for what it meant to be a man, that was not the case. Indeed, 
the public discourse about crippled veterans, veteran "tramps" and beggars, and pension advocates who seemed to be demanding government handouts offered examples of how not to be a man. It is not difficult to find in the stories and novels of the period examples of veterans who fail to measure up. In these cases, the emerging definition of Gilded Age masculinity helped articulate what was wrong with veterans. ${ }^{14}$

- One genre of stories features veterans as outcasts, shadows of the past, ghosts. They chronicle some of the war's negative long-term effects on veterans' lives and hint at some of the friction that emerged between civilians and veterans. But mainly they show that some veterans were thought of as pitiful creatures worthy of help but not respect. This attitude was foreshadowed by Henry W. Bellows, president of the U.S. Sanitary Commission, when he wrote during the war of his concern that extending too much aid to veterans would create a "class" of men "with a right to be idle, or to beg, or to claim exemption from the ordinary rules of life." This bias against institutional solutions rather than familial or local ones, together with the powerful notion that only the "deserving" poor should receive aid from their government, ensured that the men who needed help the most would have to represent the highest ideals of soldiering and of manhood. ${ }^{15}$

That sort of man appears in Louisa May Alcott's sequel, of sorts, to Hospital Sketches, which Alcott wrote for The Sword and Pen, the official newspaper of the 1881 Soldiers' Home Bazaar in Boston. Modeled after the wartime Sanitary Fair, the Bazaar was the major public fundraiser for a state soldiers' home in Massachusetts. While the serialized story presents both the great need and the obvious solution for such an institution, it also betrays the extent to which veterans could fall through the cracks in a society without a safety net.

Alcott's narrator first meets the soldier named Joe while handing out fruit to his regiment as it passes through Boston on its way to the war. She remembers him clearly half a year later, when, like Tribulation Periwinkle in Hospital Sketches, she is working as a nurse. Joe is brought into her hospital grievously wounded; his right arm has been shot off. The narrator nurses him back to health and writes letters to a fiancée back home. Although Joe recovers, his fiancée leaves him. Yet he sets aside his grief and, characteristically, gets on with his life.

A number of years pass before the narrator and Joe meet again. It has been difficult; the veteran has not been able to adapt to life without a right arm, and, like many soldiers who saw hard service, he has developed rheumatism. He has lost his farm and has no family. At the time he is working as a messenger, or "Red Cap"-hence the name of the story-as did a 
number of disabled veterans. Indeed, GAR posts and other agencies frequently set up messenger services or other light work specifically for moderately healthy men who could eke out a living serving others. Of course, he perseveres, telling the narrator that he will be fine and that, if worse comes to worse, he can go to the almshouse. Appalled, she suggests that there is hope for a better, or at least more comfortable life, at the soldiers' home proposed by Massachusetts politicians and veterans.

Whenever she sees him during the next several months-she helps out by getting her neighbors to hire him to deliver messages and do odd jobs - they talk about the progress being made on the home. Joe's rheumatism worsens, however, and he has to stop working. The narrator briefly loses touch with Joe and even hears a false rumor that he has died. She finally finds him doing housework and babysitting for a poor widow in exchange for room and board. He has been laid low with rheumatic fever; as he admits, "There ain't much left of me but bones and pain, ma'am." She promises to take him to the newly opened soldiers' home-the one they had talked about so optimistically for so long-and Joe, alone in the world, with no prospects except a pauper's grave, joyfully moves in. "A happier man or a more grateful one it would be hard to find, and if a visitor wants an enthusiastic guide about the place, Joe is the one to take, for all is comfort, sunshine, and goodwill to him; and he unconsciously shows how great the need of this refuge is, as he hobbles about on his lame feet, pointing out its beauties, conveniences, and delights with his one arm, while his face shines, and his voice quavers a little as he says gratefully,-'The State don't forget us, you see, and this is a Home wuth havin."' 16

Joe is relieved and obviously-and rightfully-thankful. But he is portrayed as a victim buffeted by bad luck and isolation who becomes a charity case aided by an individual who takes a special interest, not an honored hero reaping a deserved reward from a grateful country. The responsibility for feeling that gratitude has shifted from the nation, supposedly thankful to the saviors of the Union, to the battered warriors, desperately thankful to be institutionalized.

Other conditions could lead a troubled veteran into dependence. Whether justified or not, this generation of veterans-some of them requiring constant pain management-gained a reputation for abusing opium; indeed, for years after the war, opiate addiction was called the "soldier's disease." In addition, at least partly because of the rocky relationships between residents of soldiers' homes and the general public-to cite one common problem, warrens of cheap bars and brothels developed near virtually every one of them-veterans in those cities with homes were in constant trouble with the law. Drunkenness, and the various and often 
violent misbehaviors that accompanied it, were by far the most common disciplinary problems at the homes. ${ }^{17}$

An 1892 story by Thomas Nelson Page-published a year before his far more cheerful account of the contented train conductor-detailed this common stereotype in a sympathetic but brutal portrait of an old Confederate about whom the narrator, who had been a boy during the war, says, "I never saw such absolute dominion as the love of liquor had over him. He was like a man in chains.... He said he had a disease... and he was in absolute slavery to it." The man had never touched alcohol before the war, but he had started drinking in the army, encouraged by hardship and shared danger with convivial comrades. He had also nearly died from a bayonet wound to his chest on a day when his artillery unit had been overrun and suffered higher than 50 percent casualties during savage hand-to-hand fighting. ${ }^{18}$

All of these things led to his eventual alcoholism. Page suggested an awareness of the late-nineteenth-century discovery that addiction was more a disease than a moral failing-although the latter notion continued to shape many Americans' responses to addiction. The man had lost a fiancée and frittered away his family's money, surviving now, nearly thirty years after the war, on odd jobs, in between stints in jail for drunkenness and resisting arrest. "I have sold everything in the world I had, or could lay my hands on" to buy liquor, he confessed, but "I have never got quite so low as to sell my old gray jacket that I used to wear." The narrator lends him a little money, and from time to time he gets sober. But he inevitably falls off the wagon, and each time his condition worsens; eventually he spends more than half his time in jail: "He became a perfect vagabond, and with his clothes ragged and dirty might be seen reeling about, or standing around the street corners near disreputable bars, waiting for a chance drink, or sitting asleep in doorways of untenanted buildings."19

When word comes that his unit will hold a reunion at the dedication of a monument in Richmond, the veteran sobers up and manages to make himself presentable. During the celebration, the narrator comes across the old soldier and marvels at his fine, even youthful appearance, set off by a new set of clothes worn over, of course, his precious jacket. The recovery is temporary-the old man gets drunk and ends up in jail; the narrator talks a judge into releasing him for the festivities. In honor of his brave service decades before, the man is asked to carry the colors for his old regiment. The reunion inspires a short-lived "cure," but within a few months he is worse than ever. Soon the narrator visits him in jail, where he finds the gaunt veteran "half-naked and little better than a madman... . Body and brain were both gone." He soon dies, and as the narrator walks down the 
street, he comes across a secondhand store with a dirty, torn, blood-stained Confederate uniform jacket hanging in the window. The shop owner buys it from a pawnbroker "who had gotten it from some drunkard." It is, of course, the old veteran's jacket; he finally broke his thirty-year vow not to sell the only possession that meant more to him than alcohol. The narrator buys the jacket, puts it on the dead old soldier, and ensures that he has a "solder's burial' rather than a pauper's grave. ${ }^{20}$

"A Gray Jacket" is the sort of sentimental tale familiar to late Victorian readers, but with a Civil War twist: the conflict and tragedy-the plot itself-are all driven by the ways the war forever shadowed the men who fought it and the civilians among whom they lived. In this case, although the old soldier is viewed with pity rather than contempt, his difficulty in adapting not only to losing the war but also to peace itself indicates the major complications facing soldiers and civilians in the decades after the war. More importantly, it shows that, at least in the minds of some Americans, one old soldier stereotype depended on the drunkenness into which their traumatic youth had forced them.

- Pathetic veterans dependent on individuals or the state for small or large acts of kindness and survival were at least noticed by their fellow Americans. Another genre of stories reflected the opposite: the many veterans who simply faded into life, relatively healthy, but forgotten, ignored, irrelevant.

Hamlin Garland hinted at such an aftermath in one of the few accounts of a veteran returning from the war that gets beyond the simple joy of reuniting with family members. The story begins with several soldiers getting off a train in a little Wisconsin farm town. The townsfolk are too used to soldiers coming home to pay much attention to these dusty, tired veterans. Anxious to get home, the men separate and set out on foot.

The scene turns to the private's family, visiting a neighbor, when they spot a gaunt stranger trudge wearily up to their gate, "like a man lost in a dream. His wide, hungry eyes devoured the scene. The rough lawn, the little unpainted house, the field of clear yellow wheat behind it, down across which streamed the sun." Emma, the wife, suddenly recognizes her husband, Edward, gathers her children-an older girl, and two little boysand dashes for home. She rushes up to the startled returnee, embracing and kissing him, as the children stand in "a curious row," daughter sobbing, sons uncertain. The veteran hugs wife and daughter, then turns to the little boys. Tommy, the older one, greets him, but little Teddy hangs back, peering at his father from behind the fence. The man asks, "Come here, my little man; don't you know me?” Anticipation verges on tragic 
disappointment. Finally, the soldier produces an apple that tempts the little boy into his arms. ${ }^{21}$

After they go inside their little house, the veteran relaxes, stretched out on the floor, and catches up on family and neighborhood news. He enjoys the quiet moment but knows hard work looms ahead: "His farm was weedy and encumbered ... his children needed clothing, the years were coming upon him, he was sick and emaciated, but his heroic soul did not quail. With the same courage with which he had faced his Southern march he entered upon a still more hazardous future." Garland enhances the ambiguity of the private's return with his last sentence: "The common soldier of the American volunteer army had returned. His war with the South was over, and his fight, his daily running fight with nature and against the injustice of his fellow-men, was begun again."22

Garland's bleak look into the future for this particular veteran-he was channeling his father's constant struggle to make a living in Wisconsin and points farther west after his war service-is updated in Sarah Orne Jewett's more subtle demonstration of the long-term effects of the war on veterans and of their sometimes uneasy relationships with other Americans. "Decoration Day," published just after Memorial Day in 1892, provides New England-hued local color (Jewett's particular oeuvre) but centers on three old soldiers talking about crops and the weather outside the general store on a busy market-town evening. They had grown up together, and when the war came "they enlisted in the same company, on the same day, and happened to march away elbow to elbow." That "great experience" and the more peaceful ones that followed had led to nearly identical lives for these men who had never not known one another. They are moderately successful farmers and in their own ways proud of what they have accomplished, but they chat about other comrades who were not so fortunate: brothers and friends who had died in the war; the veteran who had fallen to drink after losing his fiancée to a stay-at-home suitor; the handful who ended up in the paupers' graveyard. ${ }^{23}$

Even the three main characters had struggled at times. "I don't know why 'twas we were so beat out," one shrugs. The ground-down young men just back from the war had scuffled to find their way, and the community noticed-although they took the wrong lesson from their observations. These fictional soldiers' quiet complaints reflected a very real issue for Civil War veterans, even Yankees, who often murmured about the men who had remained safely at home. As one of Jewett's down-easters declares, "Yes, the fellows that had staid to home got all the fat places, an' when we come back we felt dreadful behind the times." Another says, "They begun to call us hero an' stick-in-the-mud just about the same time." ${ }^{24}$ 
But the men also express their appreciation for the values the war had instilled in them, the increased sense of place and enhanced patriotism that had only grown over the years. This leads them to take the initiative in reinvigorating Memorial Day in their hamlet, which had ignored the holiday for years. "There ain't no public sperit here," one confesses. In fact, "Decoration Day" is more about reviving a lapsed appreciation for the contributions and sacrifices of veterans than about their sad lives-the old men do, indeed, rally the town to celebrate the day with appropriate sobriety and patriotism - but the first few pages paint a simple but telling portrait of the limits of northerners' memories and of the quiet desperation many veterans faced upon their return home. ${ }^{25}$

The low-level discontent expressed by these relatively well-adjusted veterans sounds quite modern; the wars of the early twenty-first century have revealed that one does not have to have been maimed or psychologically traumatized to be haunted by despair, unfocused dissatisfaction, and uneasy relationships with civilians and civilian life. It is only when the old soldiers insist on being recognized that their previously oblivious neighbors are startled into honoring them and their dead comrades.

These fictional New Englanders find a silver lining in their generally satisfactory if bittersweet lives. This is not the case for one fictional veteran in the Gilded Age: a one-handed socialist named Berthold Lindau who holds the moral center of William Dean Howells's A Hazard of Nerw Fortunes, published just two years before Jewett's story. Howells's plot centers on the bold efforts by two comfortably middle-class men to found a new kind of literary and art magazine, Every Other Week, in which the contributors would share in the profits. It is a mildly socialist counterpoint to the grasping, brusque character of New York City-the characters rather constantly talk about the nature of the metropolis, which looms large as a major character in itself-but the self-conscious generosity of Basil March and his publisher is thin gruel in the face of the true hardship faced by the city's working class and its risky resistance to the age's unbridled capitalism. Lindau, an old friend of March's from the 1850s, is a German '48er whose liberal principles survived his wounding in the Civil War and the poverty that had plagued him since. March recalls meeting him as a boy, when "Lindau was fighting the anti-slavery battle just as naturally at Indianapolis in 1858 as he fought behind the barricades at Berlin in 1848." During a bitter exchange about his reduced circumstances, the old German declares, "What gountry hass a poor man got?" The optimistic American tentatively jokes, "Well you ought to have a share in the one you helped to save for us rich men." Lindau remains silent. Later, March says that he had actually thought Lindau had died in the war; "I almost wish he had." The 
younger man is made a little sad by the older man's paltry circumstances: the shabby clothes he wears, the cheap beer he drinks, the tiny apartment that can barely hold his books. This was the only life he could make on the $\$ 12$ or $\$ 15$ monthly pension that March assumed he received "from a grateful country." 6

But Lindau did not receive a pension, it turns out. He had applied late and unsuccessfully; when Congress passed a private pension bill on his behalf, it was apparently vetoed by the president (President Grover Cleveland vetoed hundreds of such bills during his administration). $\mathrm{He}$ scrapes by as an artist's model at $\$ 6$ or $\$ 7$ a week-specializing in wizened Jewish prophets and Arabs. March manages to find a place for him on the magazine as a translator of articles and reviews from foreign journals. On another occasion, he muses about how he might actually rehabilitate his old friend's life. He would "provide ... handsomely for his old age." In this alternative future, he "got him buried with military honors, and had a shaft raised over him, with a medallion likeness ... and an epitaph., ${ }^{27}$

But most of the plot is played out in comfortable boardinghouses and middle-class apartments, artists' studios, the magazine offices, and a few mansions. Lindau is a ghost, out of step, irrelevant, a cautionary and backward-looking blast from the idealistic past. Ironically, a Confederate veteran (although his war service remains unexplored) and his daughter join the plot halfway in. When he offers an article to the magazine, suggesting that slavery could have developed into a perfect way of organizing society and protecting laborers, he and his outdated, even ridiculous ideas are tolerated, even accepted as plausible. And the former Rebel's modestly prosperous circumstances and easy entrance into polite society show the emptiness of Lindau's sacrifice.

When March visits Lindau's grim room, he realizes it bears no resemblance to that sliver of New York City in which his upper-middle-class circle works and lives. But even March, the character most sympathetic to the old soldier, is unable to break through his own limitations. All he can imagine doing is giving him a job so he can join the comfortable classes or burying him with the military honors the old soldier did not seek; he cannot integrate Lindau's values and patriotism into his own mild and moderate liberalism. Lindau fails to convince the editor to take seriously his question: "How much money can a man honestly earn without wronging or oppressing some other man?” About as far as March can get in understanding the old soldier is to realize the irony of the German's working for the establishment and in wondering at the change in his old friend from cheerful reformism to bitterness and violent political rhetoric. ${ }^{28}$ 
Lindau's amputated arm is injured by a policeman during a riot that erupts during the streetcar workers strike, and the man fails to survive the amputation of the rest of the stump. The policeman is simply an exaggerated version of other Americans-he fails to realize the old man shouting at him to stop beating other rioters is a veteran, fails to see his disability, fails to hold back as he strikes the ultimately fatal blow. Lindau becomes a martyr to American principles for a second time, but, as in the war, those principles had failed him. As a man and as a character Lindau stands apart; he has served his adopted country and sacrificed in ways the others can only imagine. In fact, they hold him at arm's length, aware of the differentness that reminds them uncomfortably of the hardships that his injury and his political beliefs have forced upon him. Unlike the optimistic and prosperous go-getters of Gilded Age New York-even friendly and relatively generous people like March-this cynical, realistic, hopelessly idealistic man measures himself not against the challenges and opportunities of New York City but against the universal values of fairness and freedom.

Howells may have been using the Civil War as a metaphorical backdrop for the labor and culture wars that characterized the period he chronicled. Yet he called Lindau his favorite character and exalted his "inherent nobleness." Critics have emphasized different aspects of Lindau's character; according to one of these, they have seen "him as a spokesman for Howells' socialism," "a source of parody," and "an advocate of violence." Yet another identifies him more as "the voice of the immigrant." All of these rather ignore one of Lindau's salient roles: a one-armed veteran of the Civil War. ${ }^{29}$

- The final genre of story offers examples of veterans as humorous, even contemptible specimens of hapless manhood. They dishonor their service with their mercenary single-mindedness in pursuing pensions and preference for government jobs. They have cynically co-opted the Republican Party and hijacked democracy to promote their own interests.

The most complete fictional version of this kind of veteran appeared in an 1896 short story in the Pocket, a humor magazine. Its author, the journalist, poet, and humorist Eugene Field, painted in very broad strokes some of the common stereotypes of veterans and veterans' organizations: greedy veterans, grasping hangers-on, and patriots corrupted by ignorance and opportunism-all enabled by the powerful GAR, which is the real target of this story and many others critical of veterans. The "hero" of the story is an easterner named Lucius, who through "conspicuous service" had risen from the ranks to become a first lieutenant during the war. Finding his old home country "cramped and restricted" after his discharge, 
he sets out for Iowa, where he does well as a farmer, marries "a likely virgin with drab ringlets and a bilious complexion" who is also the daughter of the richest and most powerful man in the county. Within a decade, he is worth $\$ 10,000$ and worthy of a portrait (for the $\$ 5 \mathrm{fee}$ ) in the pictorial history of the county. ${ }^{30}$

Things are going well for Lucius and his family, but he longs for a place to meet and talk with the "boys"--the "valorous men who did service in the war for the Union"-about the old times and to "renew in the companionship of kindred souls the old-time spirit and enthusiasm." He helps organize a small but enthusiastic GAR post, which buys a flag, a melodeon, and a few copies of a book of patriotic songs. For a number of years, it fulfills Lucius's patriotic and nostalgic needs. ${ }^{31}$

The patriotic simplicity of this small town post is deceiving, however; Field has no intention of letting the old soldiers off so easy. By the early 1880 s, when the main action of the story takes place, the GAR had begun its rapid climb to four hundred thousand members, and it was already known as a powerful political lobby for Republican candidates who supported the ever-expanding pension system. The rest of "Peace Hath Its Victories" catalogues the comic foibles of GAR members and their allies that pointedly reflects the cutthroat politics of the 1880 s and $1890 \mathrm{~s}^{32}$

The satire begins with the name of the little GAR chapter: No. 123, Corporal James Tanner Post. By the 1890s, Tanner, who had lost parts of both legs at Second Manassas, had become one of the country's most famous lecturers and advocates for veterans, but as a claims agent and frequent witness before congressional pension committees he was also a lightning rod for criticism of the pension system itself, especially after his ignominious firing after only a few months as Commissioner of Pensions in 1889. For enemies of pensions and critics of old soldiers-at least the "water coolers" and short-termers deemed by Democrats and others as unworthy of government largesse-Tanner represented all that was bad in the veteran community. He was also a leading campaigner for Republican candidates, and the fictional GAR post also successfully managed to control local elections for a number of years. ${ }^{33}$

Trouble came in 1884, when Democrats, led by President Grover Cleveland, took hold of the government and began cutting back on pensions-which, it turned out, was what the veterans in Tanner Post No. 123 were really interested in. Field touches on the fraudulent claims submitted by many veterans and their agents-at least according to their criticswith the story of a man who had lost an arm to a threshing machine but his hearing to a rainstorm while campaigning in Virginia. His case was lost, however, when records from the Meteorological Bureau proved it had not 
actually rained that month! To rub salt in the wound, the store over which the post meets burns down, destroying all of the group's meager possessions, except for a can of peaches.

Lucius steps into the breach by building his beloved post a new brick hall, which earns him the honor of becoming the post's delegate to the next national GAR encampment. It is something he had long sought-but the trip is a disaster. His fellow delegate is forced to cancel when his worried wife steals his artificial leg. Much of the final few pages of the story is a combination of a hick in the big city story-Lucius has apparently never been to the big city before, or perhaps even on a train (and the one he rides is expensive, crowded, and odiferous) - and a continuing chronicle of the cynical manipulation by unworthy veterans and entrepreneurial civilians who throng the hot, sticky streets of the unnamed city. Indeed, national encampments were extraordinary opportunities for host cities, which competed for the honor and profits of the weeklong meetings that could draw tens of thousands of old soldiers, family members, merchants, and hangers-on.

Finding all the hotels overflowing, Lucius spends too much money sharing a bed with brewery workers at a rooming house far from the city center. He is embarrassed when he asks a brass band what patriotic air they are playing and discovers it is from a comic opera he has never heard of. $\mathrm{He}$ aches to find old soldiers "to have reminiscences of the glorious old war days revived" but finds that the only veterans-and he is not even sure they are veterans-in town seem to be the ones running for office or collecting signatures for appointments to government positions (he signed fortythree such entreaties in one day!). The only member of his old regiment he located was in fact, not a soldier but the regimental sutler, who was now rich and sought the position of National Commander of the GAR, which he believes would enhance his chances of getting elected to Congress. Finally, Lucius gives his last $\$ 50$ to a swindler with a sob story about a sick daughter in Maine. The reader is left wondering if the poor old soldier will ever make it home. ${ }^{34}$

Lucius is, of course, a victim, not a villain, but he seems to represent to Fields the innocent veterans led astray by men like Corporal Tanner and other "professional soldiers" who promoted big pensions and used the Republican Party to gain sinecures in public jobs. In Field's story, such cynical "veteranizing," to use Sherwood Anderson's term for his ne'er-dowell father's constant puffing up of his own meager war record at GAR meetings and manic participation in parades and other veteran activities, spawns the kind of farce that veterans themselves enjoyed by enacting satirical initiation ceremonies like the ones in J. P. Van Nest's Ceremonial of 
the "Munchers of Hard Tack"; or, "Jordan Is Hard Road to Travel. In Gilded Age politics, however, it bred vicious attacks on veterans, as in when Puck magazine compared the pension-obsessed GAR with prostitutes and the Chicago Tribune crowed, "It will be a happy day for the republic when the last beggar of the Grand Army humbug is securely planted." 35

- One last fictional version of a Civil War veteran provides an alternative way of looking at disabled war survivors: treat them no differently than anyone else. Although written in the form of a memoir, John Smith's Funny Adventures on a Crutch seems more like a work of fiction. The author, A. F. Hill, reveals in the preface that, like his hero, he lost a leg in the war as a member of the 8th Pennsylvania Reserves, but the booka travelogue that takes place during the last few months before and the half year after the end of the war-seems to contain as much fiction as fact (the author implies that the "adventures [are] not all his"). Like Hill, Smith makes a little money by publishing an account of army life. Smith decides to spend it traveling the country, from New England to Virginia, from Philadelphia to California (via Central America). The bulk of the text describes the various sites and experiences of the peripatetic veteran; its tone is suggested when the author dedicates the book "To the Memory of Artemus Ward," the famous humorist who had died two years previously, "Whom the World Owes for a Thousand Happy Smiles."36

In addition to the travelogue, the narrative features two overriding complementary attitudes about disabled veterans. First, no one should pity them, grant them special privileges, or doubt their ability to do whatever they want or need to do. Second, veterans should embrace their condition and go about their lives with pluck and independence.

The first few chapters offer an objective, almost scientific description of his wounding in the fighting in the cornfield at Antietam. But the book features plenty of the brave reluctance to talk about their disabilities and self-deprecating humor featured in countless veterans' memoirs and fictional accounts of war injuries. Smith relates a number of humorous tales of the rowdy men assigned to a Philadelphia hospital to be fitted for artificial limbs (Smith decides not to get one-his stump is too short to carry the elaborate contraption that held an artificial limb in place-and he gets around instead on crutches and canes). "A happier, noisier, more frolicsome set of boys I never saw!" he declares. ${ }^{37}$

Smith's travels are exhausting. He is constantly getting on and off trains and steamers, climbing steps and marching up hills, jumping across streams, or strapping on ice skates. He walks twelve miles in five hours when visiting the battlefield at Antietam and on another occasion 


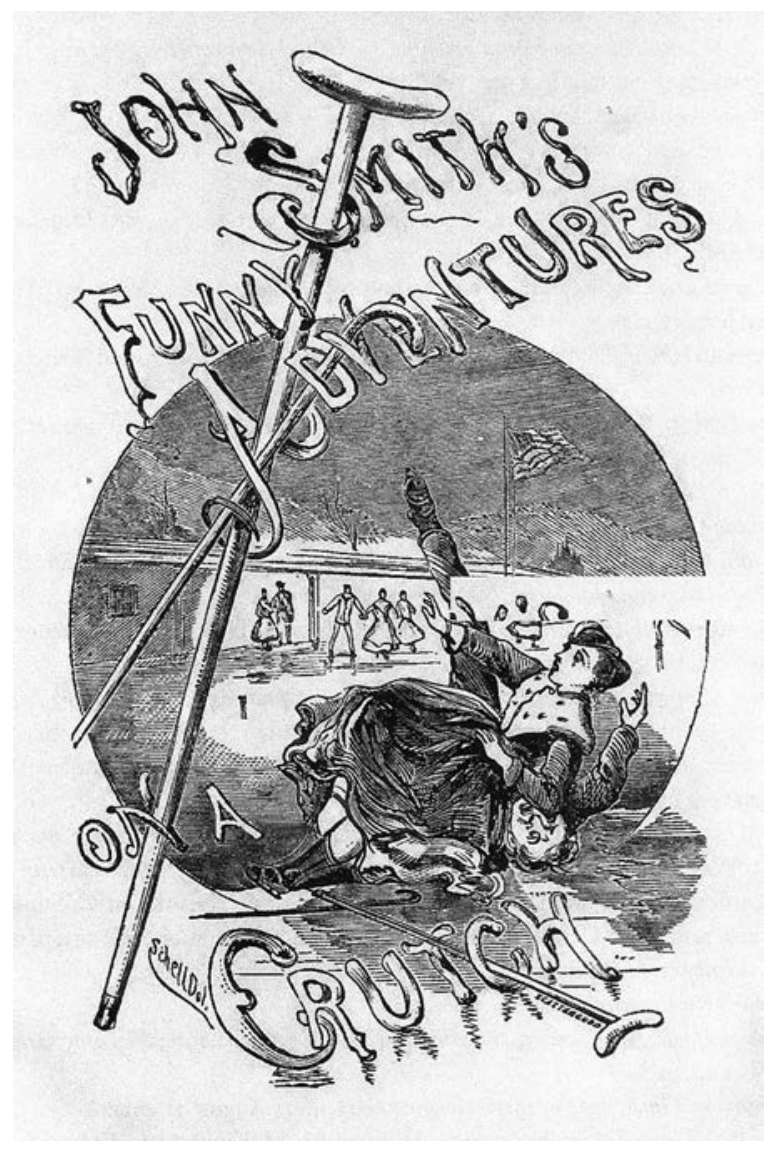

Figure 1

"John Smith" boldly

found humor in his

lightly fictionalized

memoir of disability.

Frontispiece, A. F. Hill,

John Smith's Funny

Adventures on a Crutch, or the Remarkable

Peregrinations

of a One-Legged

Soldier after the War

(Philadelphia: John E.

Potter, 1869).

disdains advice not to descend the treacherous path leading to the base of a waterfall. Although from time to time his disability does intrude, usually to inject humor into the narrative-the madcap title page illustration features him colliding with a young woman-the message is clear: there is nothing that even a grievously handicapped man cannot do. From time to time he encounters a person who doubts his abilities. He is embarrassed when a young woman offers him a dime for getting her a glass of water; she assumes he is one of the beggar-veterans who plagued the streets of New York and other cities at the end of the war. He devotes a chapter to the boilerplate answers he provides when wearisome, if compassionate, civilians ask him about his injuries.

Another chapter-“The Way Smith Gets Bored"-reveals an impatience verging on contempt for the questions people ask. "Did it ever occur to you that one who has lost a limb in the service of his country, finds it necessary 
to answer 'a question or two' now and then-to put it mildly-for some time after his return?" A disabled veteran "is looked upon as public property, and is almost bored to death with questions, by the many curious strangers he meets." He complains that he can "never have a moment's rest in any public place. I no sooner take a seat in a car, restaurant, or lecture-room, than my right-hand or left-hand lady or gentleman commences" to quiz him with a predictable battery of questions about the battle, the wound, the operation, its effect on his personal life-an endless litany of queries he has "answered thousands of times." "Imagine how it must torment me!" he asks the reader. Perhaps as bad is what inevitably follows: the questioner provides a tedious account of the experiences of a "son, nephew, cousin, or wife's uncle's brother's cousin." In other words, Smith is tired of the attention and of having to care about all the other men like him. It is time to move on. ${ }^{38}$

The breadth and scope of his travels-all accomplished in a year or less, and all paid for with the modest royalties from a war memoir-are improbable, but no more so than the extraordinary independence Smith displays. Early in the book, he briefly despairs that he will ever learn to walk on crutches. But a couple of years later, looking back, he "cannot help smiling; - now, when I can skate as fast as any one, on my solitary foot, swim as well as I ever could, climb like a squirrel, jump on a saddled horse and ride at any pace I please, place a hand on a fence as high as my head and spring over in a quarter of a second, or walk twenty-five or thirty miles a day-all this with one good leg, a crutch and a cane." All of this is, of course, ridiculous. It ignores not just the fact most men could not do any of these things when healthy but, mainly, the constant pain that most amputees endured, often for the rest of their lives. It avoids the psychological implications of the suffering and of the war's life-changing damage to his body. And it simply is not realistic to suggest that a man so wounded could have picked up his life as though nothing happened. ${ }^{39}$

But it would have been comforting to postwar civilians who had no problem honoring men who retained their limbs and their dignity and their independence. In effect, Smith gives them permission not to ask questions, not to express concern, not to consider the special needs of disabled veterans. At the same time the book empowers disabled veterans to live independently in the ways men were expected to live, it suggests that men who failed to adapt as enthusiastically and independently as Smith had somehow failed.

- Long after the war and long after veterans had passed from the public consciousness, John Steinbeck featured a Civil War veteran as a particularly 
malicious opportunist. Cyrus Trask is the father of one of the main characters in John Steinbeck's 1952 novel, East of Eden; he spends a few months in the Union army and half an hour on a battlefield, where a bullet shatters his leg. He returns with one leg and a case of venereal disease that he passes on to his wife. He writes a steady stream of letters to soldiers' papers and magazines and becomes active in the GAR. He eventually becomes a functionary in the organization, traveling the country and advising the secretary of war and president on military matters. "I wonder if you know how much influence I really have," he brags to his son. "I can throw the Grand Army at any candidate like a sock.... I can get senators defeated and I can pick appointments like apples. I can make men and I can destroy men.”40

This is a minor scene in a major novel, and there is no reason to think Steinbeck was trying to make a point about Civil War veterans in particular. Yet Cyrus Trask certainly projects some of the old soldier traits that appeared in late-nineteenth-century fiction. His greed, his exploitation of his disability for personal gain, and his mercenary manipulation of the political capital earned by Union soldiers would not have surprised Gilded Age Americans willing to think the worst of veterans. And although he appears on the far end of the veteran spectrum-he was neither pitied as helpless nor shunted from the nation's collective memory-Trask is certainly part of the complicated and often contradictory position of American veterans in the public consciousness following the Civil War.

Even Henry Fleming, the antithesis of Cyrus Trask-a relatively welladjusted, modest veteran-seems uncertain of his standing in the community. The feeling is mutual; his neighbors also do not quite know what to make of him. Crane can find no other way to end this story about a veteran than to send him once more into the burning barn. Someone remembers the colts trapped in a back corner. Henry "stared absent-mindedly at the open doors. 'The poor little things,' he said. He rushed into the barn." The other men try to stop him, but the roof collapses and both the colts and old soldier perish. Crane may be suggesting that the clearest and easiest way for Americans to remember the aging veterans in their midst was as dead heroes, not the complicated men they had actually become. ${ }^{41}$

NOTES

The author thanks Matt Gallman for his valuable comments on an earlier draft of this article.

1. Stephen Crane, “The Veteran," McClure's 7 (August 1896): 224.

2. Dora L. Costa, The Evolution of Retirement: An American Economic History, 1880-1980 (Chicago: University of Chicago Press, 1998), 198; Paul D. Escott, Military Necessity: Civil-Military Relations in the Confederacy (Westport, Conn.: Praeger, 
2006), 165-66. In the last thirty years, a number of historians have devoted all or significant portions of books to issues facing veterans of the Civil War. They include Fred A. Bailey, Class and Tennessee's Confederate Generation (Chapel Hill: University of North Carolina Press, 1987); Peter S. Carmichael, The Last Generation: Young Virginians in Peace, War, and Reunion (Chapel Hill: University of North Carolina Press, 2005); Eric T. Dean Jr., Shook over Hell: Post-Traumatic Stress, Vietnam, and the Civil War (Cambridge, Mass.: Harvard University Press, 1999); Barbara A. Gannon, The Won Cause: Black and White Comradeship in the Grand Army of the Republic (Chapel Hill: University of North Carolina Press, 2011); Russell L. Johnson, Warriors into Workers: The Civil War and the Formation of Urban-Industrial Society in a Northern City (New York: Fordham University Press, 2003); Larry M. Logue and Michael Barton, eds., The Civil War Veteran: A Historical Reader (New York: New York University Press, 2007); Jeffrey W. McClurken, Take Care of the Living: Reconstructing Confederate Veteran Families in Virginia (Charlottesville: University of Virginia Press, 2009); James Marten, Sing Not War: The Lives of Union and Confederate Veterans in Gilded Age America (Chapel Hill: University of North Carolina Press, 2011); Stuart McConnell, Glorious Contentment: The Grand Army of the Republic, 1865-1900 (Chapel Hill: University of North Carolina Press, 1992); Donald R. Shaffer, After the Glory: The Struggles of Black Civil War Veterans (Lawrence: University Press of Kansas, 2004). See also dissertations by Kathleen Lynn Gorman, "When Johnny Came Marching Home Again: Confederate Veterans in the New South" (PhD diss., University of CaliforniaRiverside, 1994) and Robert A. Hagaman, "Personal Battles: The Lives of Maryland's Black Civil War Veterans, 1840-1920” (PhD diss., Northern Illinois University, 2004).

3. O. T. Beard, Bristling with Thorns: A Story of War and Reconstruction (Detroit: Detroit News Company, 1884); Thomas Dixon Jr., The Clansman, an Historical Romance of the Ku Klux Klan (New York: Doubleday, Page, 1905); Edgar Rice Burroughs, Under the Moon of Mars (New York: A. C. McClurg, 1917).

4. Albion Winegar Tourgée, A Fool's Errand; by One of the Fools (New York: Fords, Howard, \& Hulbert, 1879), 21, 33.

5. Charles W. Chesnutt, The Colonel's Dream (New York: Doubleday, Page, \& Co., 1905).

6. William Dean Howells, The Rise of Silas Lapham (New York: Houghton Mifflin, 1885). See for instance, Donald E. Pease, ed. New Essays on the Rise of Silas Lapham (New York: Cambridge University Press, 1991).

7. David W. Blight, Race and Reunion: The Civil War in American Memory (Cambridge, Mass.: Harvard University Press, 2001); Caroline E. Janney, Remembering the Civil War: Reunion and the Limits of Reconciliation (Chapel Hill: University of North Carolina Press, 2013).

8. Thomas Nelson Page, "How the Captain Made Christmas," Scribners 14 (December 1893): 779-86; Randall Parrish, Keith of the Border: A Tale of the Plains (Chicago: A. C. McClurg, 1910), 14-15.

9. Edward Lucas White, “The Little Faded Flag," Atlantic Monthly, May 1908, 637. 10. Ibid., 643. 
11. Willa Cather, "The Sculptor's Funeral," in Willa Cather: Collected Short Fiction, 1892-1912, ed. Virginia Faulkner (Lincoln: University of Nebraska Press, 1970), 173-74.

12. Abraham Lincoln, second inaugural address, The Collected Works of Abraham Lincoln. 8 vols., ed. Roy P. Basler (New Brunswick, N.J.: Rutgers University Press, 1953), 8:333.

13. For two quite recent accounts of Civil War veterans in literature, see Craig A. Warren, Scars to Prove It: The Civil War Soldier and American Fiction (Kent, Ohio: Kent State University Press, 2009), and Avent Childress Beck, "Civil War Veterans in the Fiction of Samuel Clemens, William Dean Howells, Henry Adams, and Henry James" (PhD diss., New York University, 2003).

14. Marten, Sing Not War, 21-28. On manhood see, for example, E. Anthony Rotundo, American Manhood: Transformations in Masculinity from the Revolution to the Modern Era (New York: Basic Books, 1993), esp. 136-37, 178-81; and Gail Bederman, Manliness and Civilization: A Cultural History of Gender and Race in the United States, 1880-1917 (Chicago: University of Chicago Press, 1995). Bederman does not agree that there was a crisis but provides excellent definitions of the evolving notions of manhood during the era.

15. Henry W. Bellows to Stephen Perkins, August 15, 1862, in U.S. Sanitary Commission, Documents of the United States Sanitary Commission, 3 vols. (New York: n.p., 1885), 1:2. The standard history of the federal soldiers' home system is Patrick J. Kelly, Creating a National Home: Building the Veterans' Welfare State, 1860-1900 (Cambridge: Harvard University Press, 1997). For Confederate state homes, see R. B. Rosenburg, Living Monuments: Confederate Soldiers' Homes in the New South (Chapel Hill: University of North Carolina Press, 1993).

16. Louisa May Alcott, "My Red Cap," Sword and the Pen, December 7, 8, 9, 1881, 3-4, 3-4, 3-4. Alcott's sketches were published in serial and then as a book nearly twenty years earlier. Louisa May Alcott, Hospital Sketches (New York: James Redpath, 1863).

17. Marten, Sing Not War, 100-120. The classic account of the "soldier's disease" is David T. Courtwright, "Opiate Addiction as a Consequence of the Civil War," Civil War History 24 (June 1978): 101-11.

18. Thomas Nelson page, “A Gray Jacket," Century 44 (May 1892): 29.

19. Ibid.

20. Ibid., 29, 33. Page does not specify which monument was being dedicated, but on May 30, 1892, the monument to Gen. A. P. Hill was dedicated at Northside, Richmond. Katarina M. Spears, Richmond Landmarks (Mount Pleasant, S.C.: Arcadia, 2012), 40.

21. Hamlin Garland, "The Return of the Private," in Main-Travelled Roads (New York: Harper, 1899), 6-8. Garland recounts his own father's homecoming in late summer 1865 at the beginning of his autobiography, Son of the Middle Border (New York: Collier's, 1917), 2-13.

22. Ibid., 11.

23. Sarah Orne Jewett, “Decoration Day, Harper's New Monthly Magazine 85 (June 1892): 84 . 
24. Ibid., 86.

25. Ibid., 85.

26. William Dean Howells, A Hazard of New Fortunes (Bloomington: Indiana University Press, 1976), 94, 95, 96.

27. Theda Skocpol, Protecting Soldiers and Mothers: The Political Origins of Social Policy in United States (Cambridge: Harvard University Press, 1992), 121-23; Howells, Hazard of New Fortunes, 151.

28. Howells, Hazard of New Fortunes, 191.

29. Jonathon Bauch, "Public German, Private Jew: The Secret Identity of Berthold Lindau in Howells' A Hazard of New Fortunes," American Literary Realism 41 (Fall 2008): 14.

30. Eugene Field, "Peace Hath Its Victories," Pocket Magazine 1 (February 1896): 58.

31. Ibid., 60.

32. Larry M. Logue, To Appomattox and Beyond: The Civil War Soldier in War and Peace (Chicago: Ivan R. Dee, 1995), 93-95.

33. James Marten, America's Corporal: James Tanner in War and Peace (Athens: University of Georgia Press, 2014), esp. chap. 4. A few economists and legal historians have offered intriguing papers on the effects of pensions on Union veterans. See, for example, Peter Blanck and Chen Song, “Never Forget What They Did Here': Civil War Pensions for Gettysburg Union Army Veterans and Disability in Nineteenth-Century America," William and Mary Law Review 44 (February 2003): 1109-71; Peter Blanck, "Civil War Pensions and Disability," Ohio State Law Journal 62 (2001): 109-238; Chulhee Lee, "Wealth Accumulation and the Health of Union Army Veterans, 18601870," Journal of Economic History 65 (June 2005): 352-85.

34. Field, "Peace Hath Its Victories," 71.

35. Quoted in Gerald Linderman, Embattled Courage: The Experience of Combat in the American Civil War (New York: Free Press, 1987), 280; J. P. Van Nest, Ceremonial of the "Munchers of Hard Tack"; or, "Jordan Is Hard Road to Travel (Greenville, Ill.: De Moulin, 1888); Puck, September 20, 1893, quoted in Ohio Soldier, October 7, 1888.

36. A. F. Hill, John Smith's Funny Adventures on a Crutch, or the Remarkable Peregrinations of a One-Legged Soldier after the War (Philadelphia: John E. Potter, 1869), n.p. Thanks to Anne Sarah Rubin for bringing this book to my attention. Hill's war memoir was called Our Boys: The Personal Experiences of a Soldier in the Army of the Potomac (Philadelphia: John E. Potter, 1865). Some digital libraries (there are several that offer full editions of his books) identify Hill as Rev. Alonzo Hill, who died in 1871 (for example, see the entry for the novel found at the Internet Archive, https:// archive.org/details/johnsmithsfunnyaoohill). But he was actually Ashbel Fairchild Hill. A genealogical website offers a photograph that matches the author's image in one of his books and provides a short biographical statement indicating that Hill was editor of several newspapers in New England and California and author of several books about the war and the publishing business. He died in Pennsylvania in 1876 at the age of thirty-four. "Pvt. A. F. Hill," Findagrave.com, accessed July 18, 2014, http://www. findagrave.com/cgi-bin/fg.cgi?page $=$ gr\&GRid=53866674 . 
37. Frances M. Clarke, War Stories: Suffering and Sacrifice in the Civil War North (Chicago: University of Chicago Press, 2011), 51-83; Cameron C. Nickels, Civil War Humor (Jackson: University Press of Mississippi, 2010), 88; Smith, John Smith's Funny Adventures, 19.

38. Smith, John Smith's Funny Adventures, 48, 50.

39. Ibid., 17 .

40. John Steinbeck, East of Eden (New York: Penguin, 1992), 52-53.

41. Crane, "Veteran," 224 